\title{
Studi In Silico Metabolit Sekunder Kapang Monascus sp. Sebagai Kandidat Obat Antikolesterol dan Antikanker
}

\author{
Marlia Singgih $^{a}$, Benny Permana ${ }^{a}$, Selvira Anandia Intan Maulidya ${ }^{a}$, Anna Yuliana ${ }^{b^{*}}$ \\ ${ }^{a}$ Sekolah Farmasi, Institut Teknologi Bandung, Jl. Ganesha 10, Bandung 40132 \\ ${ }^{b}$ Program Studi Farmasi, STIKes BTH Tasikmalaya, Jl. Cilolohan 36, Tasikmalaya 46115 \\ *Corresponding author \\ E-mail:a_joely@yahoo.co.id \\ DOI: 10.20961/alchemy.15.1.25294.104-123
}

Received 13 November 2018, Accepted 21 January 2019, Published 01 March 2019

\begin{abstract}
ABSTRAK
Kapang Monascus sp. secara tradisional telah digunakan dalam fermentasi beras merah (angkak) yang bermanfaat sebagai pewarna makanan, pengawet makanan maupun obat-obatan. Saat ini, beras angkak telah menjadi suplemen makanan yang terkenal karena banyaknya senyawa bioaktif yang terkandung seperti monakolin, pigmen, asam dimerumat dan lain-lain. Tujuan penelitian ini adalah untuk menemukan metabolit sekunder kapang Monascus sp. yang meliputi senyawa monakolin dengan efek antikolesterol, pigmen dengan efek antikanker pada kanker payudara serta memprediksi toksisitas senyawa melalui studi in silico. Senyawa uji terdiri dari 14 senyawa monakolin dan 33 pigmen Monascus sp. Protein HMG KoA (3-hidroksi-3metilglutaril koenzim A) reduktase digunakan sebagai reseptor antikolesterol sementara estrogen alfa, estrogen beta, dan aromatase digunakan sebagai reseptor antikanker. Perangkat lunak AutoDock digunakan untuk menganalisis kompleks struktural reseptor dengan senyawa uji. Prediksi toksisitas dilakukan menggunakan perangkat lunak ADMET predictor dan QSAR Toolbox. Prediksi toksisitas dan hasil docking menunjukkan bahwa asam monakolin L menunjukkan aktivitas antikolesterol yang baik terhadap HMG KoA reduktase; pigmen monaskin menunjukkan aktivitas antikanker yang selektif terhadap reseptor estrogen beta; dan keduanya diprediksi aman. Prediksi toksisitas senyawa monakolin dan pigmen Monascus sp. menunjukkan terdapat 7 senyawa monakolin yaitu 3-hidroksi-3,5-dihidromonakolin L, asam dihidromonakolin L, monakolin L, asam monakolin J, monakolin J, asam monakolin L, monakolin M, dan 5 pigmen Monascus sp. yaitu ankaflavin, monaskin, monaskopiridin A, monaskopiridin B dan monascuspiloin yang dinyatakan tidak toksik. Tujuh pigmen Monascus sp. yang terdiri dari monankarin A, monankarin B, monankarin $\mathrm{C}$, monankarin $\mathrm{D}$, monankarin $\mathrm{E}$, monankarin $\mathrm{F}$, dan monasfluol $\mathrm{A}$ bersifat positif mutagen, karsinogen dan toksik terhadap reproduksi. Hasil penelitian ini berpotensi dapat diaplikasikan untuk desain dan pengembangan obat antikolesterol dan antikanker.
\end{abstract}

Kata kunci: in silico, metabolit sekunder, Monascus sp, toksisitas

\begin{abstract}
In Silico Study of Secondary Metabolites of Monascus sp. As A Candidate for Anticholesterol and Anticancer Drugs. The fungus Monascus sp. has traditionally been used to prepare red fermented rice (angkak) as a natural food colorant, food preservative or medicinal agent. Recently, it has become a popular dietary supplement due to many of its bioactive constituents such as monacolin compounds, pigments, and dimerumic acid, etc. These functional constituents also had been deemed to be provided with various health benefits. This research aims to find secondary metabolites of monacolin compounds with
\end{abstract}


antihypercholesterolemic effect, Monascus sp. pigment with anticancer effect on breast cancer, and predict their toxicity through in silico study. The studied compounds consist of 14 monacolin compounds and 33 Monascus sp. pigments. HMG CoA (3-hydroxy-3-methylglutaryl Coenzyme A) reductase protein was used as antihypercholesterolemic receptor in which estrogen alfa, estrogen beta, and aromatase were used as anticancer receptors. AutoDock docking software was used to analyze structural complexes of the receptors with studied compounds. Toxicity prediction was done using ADMET predictor and QSAR Toolbox softwares. Toxicity prediction and docking results revealed that monacolin $\mathrm{L}$ acid exhibits good anticholesterol activity towards HMG CoA reductase; monascin pigment exhibits selective anticancer activity towards estrogen beta receptor; and both of them were predicted to be safe. Toxicity prediction of studied compounds showed that 7 monacolin compounds which are 3-hydroxy-3,5-dihydromonakolin L, dihydromonacolin $\mathrm{L}$ acid, monacolin $\mathrm{L}$, monacolin $\mathrm{J}$ acid, monacolin $\mathrm{J}$, monacolin $\mathrm{L}$ acid, monacolin $\mathrm{M}$ and 5 Monascus sp. pigments which are ankaflavin, monascin, monascopyridine A, monascopyridine B dan monascuspiloin are not toxic. Seven Monascus sp. pigments which are monankarin A, monankarin B, monankarin $\mathrm{C}$, monankarin $\mathrm{D}$, monankarin $\mathrm{E}$, monankarin $\mathrm{F}$ and monasfluol $\mathrm{A}$ are mutagenic, carcinogenic and also reprotoxic. The research results could be useful for the design and development of the anticholesterol and anticancer drugs.

Keywords: in silico, Monascus sp., secondary metabolite, toxicity

\section{PENDAHULUAN}

Monascus sp. merupakan kapang yang digunakan untuk fermentasi beras sehingga dihasilkan beras merah (Red Mold Rice) atau angkak. Beras ini telah lama digunakan pada makanan Asia dan pengobatan tradisional. Angkak mengandung banyak senyawa bioaktif, termasuk monakolin yang berpotensi untuk digunakan sebagai nutraceutical (Nguyen et al., 2017). Monakolin merupakan senyawa turunan poliketida yang memiliki kemampuan untuk menurunkan kadar lipid dalam darah. Salah satu senyawa monakolin yang telah banyak diteliti yaitu monakolin K, suatu inhibitor kuat HMG KoA (3-hidroksi-3metilglutaril koenzim A) reduktase yang terbukti efektif mengurangi kolesterol dan trigiliserida (Sabry, 2016). Beberapa penelitian menunjukkan bahwa angkak yang mengandung 5 - 10 mg monakolin K menurunkan kadar LDL-C sebesar 22 sampai 27\%

(Heinz et al., 2016). Terdapat empat belas senyawa monakolin yang diketahui terkandung dalam beras angkak namun belum diketahui apakah memiliki aktivitas antikolesterol seperti senyawa monakolin $\mathrm{K}$.

Saat ini, pigmen yang dihasilkan Monascus sp. antara lain berwarna kuning (ankaflavin, monaskin), oranye (rubropunktatin, monaskorubrin) dan merah (rubropunktamin, monaskorubramin) yang memiliki berbagai aktivitas biologis (Wongjewboot and Kongruang, 2011). Pigmen Monascus sp. banyak digunakan sebagai pewarna dan perasa makanan dalam industri makanan terutama untuk ikan seperti pasta ikan, surimi dan produk daging seperti sosis dan ham. Selain itu, pigmen ini dapat dimanfaatkan tidak terbatas hanya pada bidang makanan saja namun juga industri kosmetik dan farmasi (Seyedin et al., 2015). 
Pigmen Monascus sp. juga memiliki aktivitas antibiotik terhadap bakteri, aktivitas sitotoksik maupun sitostatik, serta mampu menghambat pertumbuhan tumor (Ho and Pan, 2009). Penelitian Fatima et al. (2014) menunjukkan bahwa berdasarkan studi in silico, pigmen Monascus sp. memiliki potensi sebagai obat kanker payudara dengan reseptor hormon positif. Menurut WHO (World Health Organization), kanker payudara merupakan kanker yang paling sering terjadi pada wanita, menjangkiti 2,1 juta wanita setiap tahunnya dan menjadi penyebab tertinggi kematian wanita karena kanker.

Penelitian pigmen Monascus sp. telah berkembang sangat cepat termasuk penemuan pigmen-pigmen baru, metode yang digunakan dan identifikasinya. Saat ini hampir 57 pigmen baru telah ditemukan yang merupakan derivat dari enam pigmen utama yang telah ada (Yuliana et al., 2017). Namun informasi terkait aktivitas dan keamanannya masih terbatas. Metode toksikologi in silico mampu memberikan gambaran informasi terkait toksisitas suatu senyawa serta membantu mengidentifikasi toksisitas senyawa agar dapat dilakukan pemilihan calon senyawa untuk dikembangkan menjadi kandidat obat baru. Metode ini juga sebagai pelengkap dalam uji in vitro dan in vivo sehingga penggunaan hewan, biaya dan waktu berkurang (Raies and Bajic, 2016). Penelitian ini bertujuan untuk menemukan metabolit sekunder kapang Monascus sp. yang meliputi senyawa monakolin dengan efek antikolesterol, pigmen dengan efek antikanker pada kanker payudara serta memprediksi toksisitas senyawa melalui studi in silico.

\section{METODE PENELITIAN}

Senyawa uji diperoleh dari PubChem berdasarkan data eksperimental beberapa penelitian ilmiah yaitu 14 senyawa monakolin dan 33 senyawa pigmen. Data struktur 3D kristal protein yang digunakan untuk penambatan molekuler diperoleh dari Protein Data Bank (PDB) yaitu reseptor HMG KoA reductase (Kode PDB: 1HW9), reseptor estrogen alfa (Kode PDB: 3ERT), reseptor estrogen beta (Kode PDB: 1X7J) dan reseptor aromatase (Kode PDB: 3S7S). Senyawa kontrol untuk verifikasi metode prediksi toksisitas perangkat lunak didapat dari data CLP (Classification, Labelling and Packaging) 2008 yaitu sebanyak 50 senyawa untuk uji karsinogenitas dan mutagenitas dan 50 senyawa kontrol untuk uji toksisitas reproduksi. Senyawa tersebut terdiri dari 25 senyawa untuk kontrol positif dan 25 senyawa untuk kontrol negatif. Perangkat keras yang digunakan yaitu laptop dengan processor Intel® Core $^{\mathrm{TM}}$ i5 CPU @1.6 GHz RAM 8GB dengan sistem operasi macOS High Sierra, komputer server dengan processor Intel® Xeon® X5650@2.67GHz RAM 48 GB dengan sistem operasi Windows 7 Profesional dan komputer dengan 
processor Intel® Core $^{\mathrm{TM}}$ i5-2320 CPU @3.00 GHz RAM 6GB dengan sistem operasi Windows 7 Profesional. Perangkat lunak yang digunakan adalah ChemDraw 3D, Gaussian 09w (Frisch et al., 2016), Autodock 4.2.6 (Morris et al., 2009), Discovery Studio 2017 (Dassault Systemes BIOVIA, 2018, iBabel (O’Boyle et al., 2011), ADMET Predictor v7 (Watkins et al., 2018), dan OECD QSAR Toolbox v3.4.

\section{Optimasi Geometri Senyawa Uji}

Senyawa uji yang akan dilakukan penambatan molekuler terlebih dahulu dioptimasi dengan perangkat lunak Gaussian 09w. Metode optimasi yaitu Density Functional Theory (DFT) dengan fungsi B3LYP dan Basis Set 6-311G.

\section{Validasi Metode Docking}

Validasi dilakukan dengan metode redocking menggunakan ligan alami yang terdapat pada reseptor. Proses penambatan molekuler dilakukan dengan menambatkan kembali ligan alami pada reseptornya meggunakan perangkat lunak Autodock 4.2.6. Parameter yang digunakan untuk menilai validitas yaitu nilai Root Mean Square Deviation (RMSD) dari konformasi ligan terbaik hasil redocking tersebut yang merupakan nilai simpangan posisi ruang ligan hasil docking dibandingkan dengan posisi ligan hasil kristalografi. Luaran yang diharapkan yaitu nilai RMSD kurang dari 2,0 A sehingga dinyatakan valid (Sherman et al., 2006).

\section{Penambatan Molekul}

Protein dan senyawa uji dipreparasi dengan Autodock 4.2.6. Sebelum proses penambatan molekuler dimulai, terlebih dulu disiapkan pengaturan parameter grid box. Dimensi grid box disesuaikan dengan ukuran ligan masing-masing, sedangkan koordinat grid box menggunakan koordinat pusat dari ligan alami. Parameter penambatan molekuler digunakan metode perhitungan genetic algorithm (GA) dan jumlah GA runs sebanyak 100 kali. Ligan dan reseptor yang telah dipreparasi kemudian disatukan dalam satu folder dan dilanjutkan dengan proses gridding dan docking. Senyawa monakolin dilakukan penambatan molekuler terhadap reseptor HMG KoA reduktase sedangkan pigmen Monascus sp. dilakukan penambatan molekuler terhadap reseptor estrogen alfa, estrogen beta dan aromatase. Hasil akhir penambatan molekuler didapat sebanyak 100 konformasi senyawa. Penentuan konformasi ligan terbaik dilakukan berdasarkan energi ikatan terendah. Hasil docking terbaik divisualisasikan menggunakan Discovery Studio ${ }^{\circledR}$ dan dilihat residu asam amino dan ikatan hidrogennya. 


\section{Verifikasi Metode Prediksi Toksisitas}

Verifikasi metode prediksi toksisitas dilakukan terhadap metode yang digunakan untuk prediksi mutagenitas, karsinogenitas, dan toksisitas reproduksi. Verifikasi dilakukan dengan menggunakan Classification Model yang hasilnya dibagi ke dalam dua kategori, yaitu positif (toksik) dan negatif (non-toksik). Hasil verifikasi disusun dalam bentuk matriks yang disebut dengan matriks konfusi disajikan pada Tabel 1.

Tabel 1. Matriks konfusi

\begin{tabular}{cccc}
\hline \multirow{2}{*}{ Eksperimen } & \multicolumn{2}{c}{ Prediksi } & \multirow{2}{*}{ Jumlah } \\
\cline { 2 - 3 } & + & - & \\
\hline+ & $\mathrm{TP}$ & $\mathrm{FN}$ & $\mathrm{TP}+\mathrm{FN}$ \\
- & $\mathrm{FP}$ & $\mathrm{TN}$ & FP+TN \\
Jumlah & $\mathrm{TP}+\mathrm{FP}$ & $\mathrm{FN}+\mathrm{TN}$ & $\mathrm{TP}+\mathrm{FN}+\mathrm{FP}+\mathrm{TN}$ \\
\hline
\end{tabular}

Keterangan $: \mathrm{TP}=$ True Positive, $\mathrm{TN}=$ True Negative, $\mathrm{FP}=$ False Positive, $\mathrm{FN}=$ False Negative

Parameter verifikasi meliputi sensitivitas, spesifisitas, akurasi, prediksi positif, prediksi negatif, rasio positif palsu, rasio negatif palsu, ROC (Receiver Operating Characteristic) positif dan ROC negatif.

\section{Prediksi Toksisitas}

Toksisitas senyawa uji dianalisis yang terdiri atas prediksi mutagenitas, karsinogenitas, toksisitas reproduksi dan toksisitas akut (LD50). Prediksi mutagenitas digunakan perangkat lunak ADMET Predictor v7 dan QSAR Toolbox v3.4. Prediksi karsinogenitas digunakan perangkat lunak QSAR Toolbox v3.4. Prediksi toksisitas reproduksi dan toksisitas akut digunakan perangkat lunak ADMET Predictor v7.

\section{HASIL DAN PEMBAHASAN}

\section{Validasi Metode Penambatan Molekul}

Penambatan molekuler atau molecular docking harus divalidasi terlebih dahulu untuk memastikan bahwa metode docking yang digunakan memiliki keakuratan pose geometrik. Validasi dilakukan dengan teknik redocking ligan alami pada masing-masing reseptor yang digunakan. Redocking merupakan proses memisahkan ligan alami dengan struktur kristal reseptornya kemudian dilakukan docking kembali pada reseptor tersebut. Parameter docking dinyatakan valid apabila nilai RMSD dari hasil redocking yaitu $\leq 2,0 \AA$ (Sherman et al., 2006). 


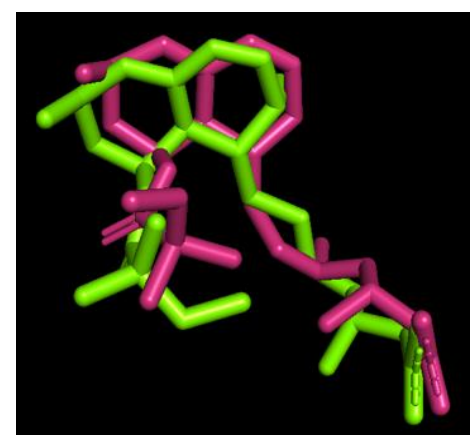

(a)

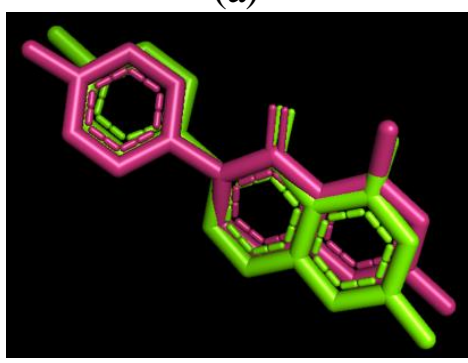

(c)

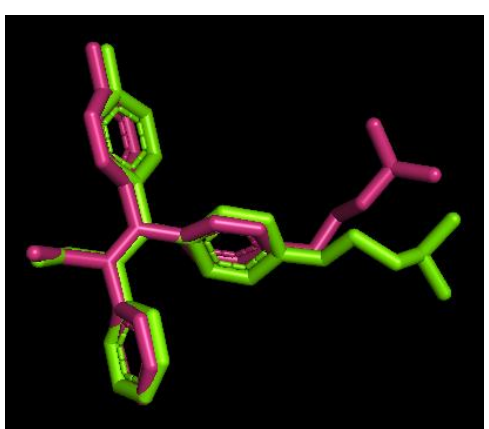

(b)

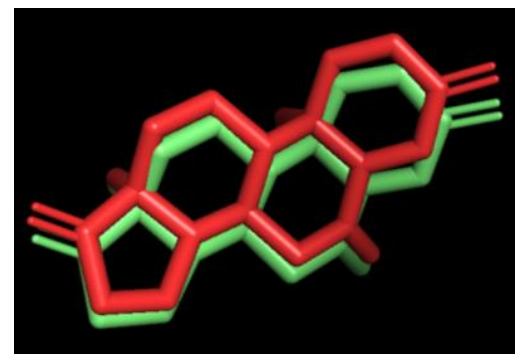

(d)

Gambar 1. Visualisasi hasil redocking (a) ligan alami simvastatin (hijau) dan ligan hasil redocking (merah) (b) ligan alami 4-hidroksitamoksifen (hijau) dan ligan hasil redocking (merah) (c) ligan alami genistein (hijau) dan ligan hasil redocking (merah) (d) ligan alami exemestane (hijau) dan ligan hasil redocking (merah)

Berdasarkan hasil redocking (Gambar 1) seluruh target reseptor yang digunakan dalam studi in silico ini memiliki nilai RMSD $<2,0 \AA$. Hal ini menunjukkan bahwa perangkat lunak AutodockTools dapat menempatkan kembali posisi ligan pada posisinya semula dengan pergeseran $<2,0 \AA$ antara ligan alami dan ligan hasil redocking sehingga memenuhi kriteria validitas.

\section{Penambatan Molekul Monakolin}

Secara keseluruhan terdapat 14 senyawa monakolin yang telah ditemukan terkandung secara alami pada beras angkak. Gambar struktur senyawa monakolin tersebut dapat dilihat pada Gambar 2.

Docking senyawa monakolin dilakukan terhadap reseptor HMG KoA reduktase untuk melihat aktivitas antikolesterol. Penambatan molekul monakolin akan menghasilkan prediksi energi dan juga bentuk pose interaksi yang divisualisasikan. Energi bebas ikatan $(\Delta \mathrm{G})$ pada hasil perhitungan penambatan secara default berkolerasi dengan nilai Konstanta inhibisi (Ki). Perhitungan energi bebas ikatan bertujuan menggambarkan afinitas ikatan dan stabilitas kompleks yang terbentuk. Hasil docking dan interaksi ligan-reseptor dapat dilihat pada Tabel 2. 


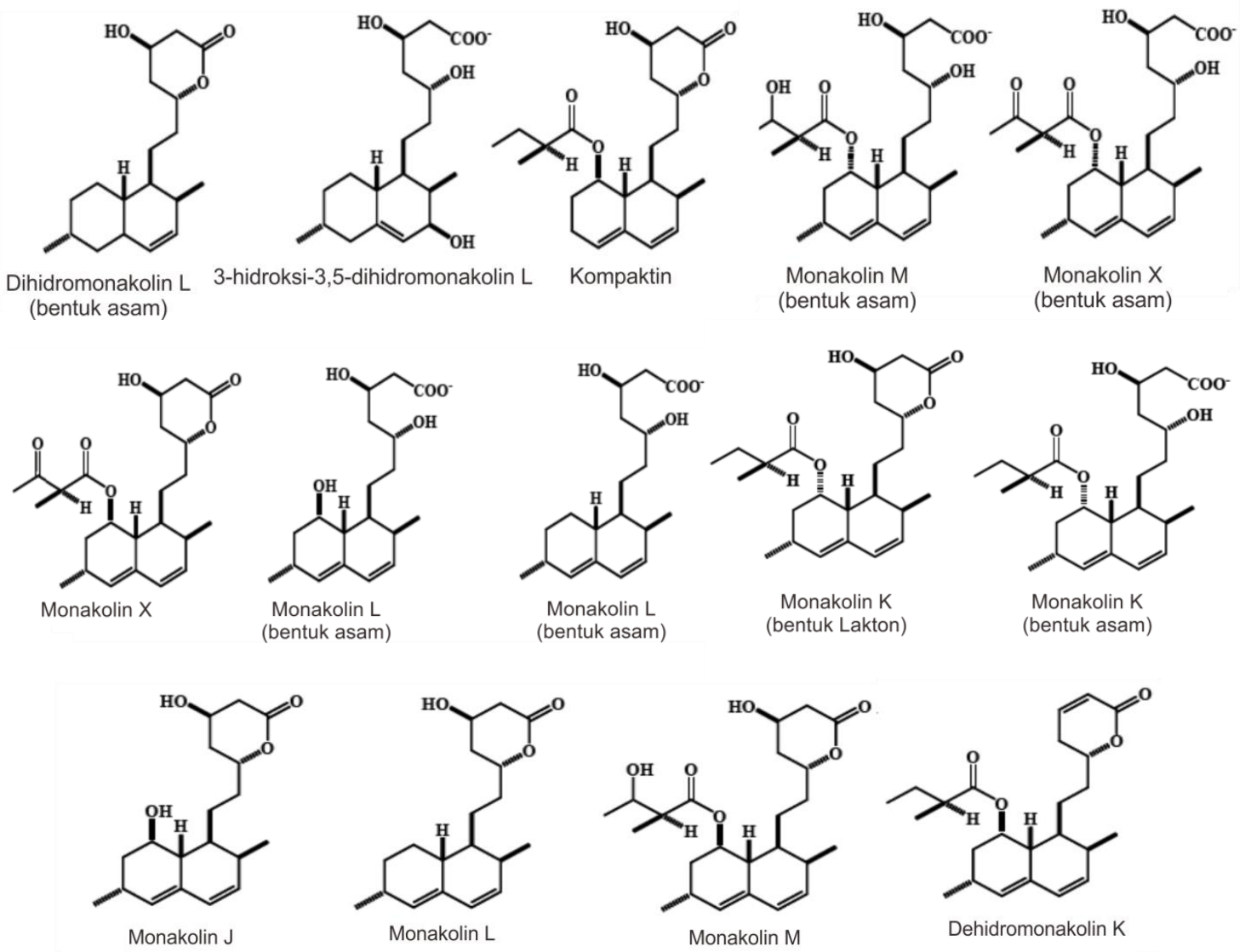

Gambar 2. Struktur senyawa monakolin (Sabry, 2016)

Tabel 2. Hasil docking senyawa monakolin pada reseptor HMG KoA reduktase

\begin{tabular}{cllcc}
\hline No & \multicolumn{1}{c}{ Nama Senyawa } & \multicolumn{1}{c}{ Ikatan Hidrogen } & $\begin{array}{c}\text { Energi } \\
\text { Ikatan } \\
(\text { Kkal/mol) }\end{array}$ & $\begin{array}{c}\text { Ki } \\
(\mu \mathbf{M})\end{array}$ \\
\hline 1 & asam monakolin L & Glu559, Asn755, Ala751, Lys735 & $-6,1$ & 33,61 \\
2 & asam dihidromonakolin L & Glu559, Lys735, Ala751 & $-5,99$ & 40,55 \\
3 & kompaktin & Glu559 & $-5,94$ & 44,02 \\
4 & 3-hidroksi-3,5- & Glu559, Lys735 & $-5,86$ & 50,9 \\
& dihidromonakolin L & & & \\
5 & asam monakolin X & Glu559 & $-5,75$ & 60,87 \\
6 & monakolin L & Glu559 & $-5,73$ & 63,2 \\
7 & monakolin J & Glu559, Asn755, Ser565, Gly560 & $-5,71$ & 64,92 \\
8 & monakolin X & Lys735, Ser565 & $-5,61$ & 76,61 \\
9 & Simvastatin (Ligan Alami) & Glu559, Asn755 & $-5,61$ & 76,76 \\
10 & dehidromonakolin K & - & $-5,57$ & 82,23 \\
11 & monakolin K & Gly860 & $-5,48$ & 96,93 \\
12 & asam monakolin J & Glu559, Asn755, Ala751, Lys735 & $-5,31$ & 128,41 \\
13 & monakolin M & Glu559, Asn755, Ser565, His752 & $-5,17$ & 162,73 \\
14 & asam monakolin K & Glu559, Asn755, Ala751, Lys735 & $-4,85$ & 279,19 \\
15 & asam monakolin M & Glu559, Asn755, Ser565 & $-4,71$ & 354,73 \\
\hline
\end{tabular}


Berdasarkan Tabel 2, terdapat delapan senyawa monakolin yang memiliki energi bebas ikatan lebih kecil dibandingkan ligan alami, secara berurutan dari energi terkecil yaitu asam monakolin L, asam dihidromonakolin L, kompaktin, 3-hidroksi-3,5dihidromonakolin $\mathrm{L}$, asam monakolin $\mathrm{X}$, monakolin $\mathrm{L}$, monakolin $\mathrm{J}$ dan monakolin $\mathrm{X}$. Semakin kecil nilai energi bebas ikatan maka konformasi yang terbentuk semakin stabil dan sebaliknya, semakin besar nilai energi bebas maka konformasi yang terbentuk semakin kurang stabil. Semakin negatif nilai yang dihasilkan, maka afinitas kompleks ligan-protein yang terbentuk semakin baik sehingga diharapkan aktivitasnya pun akan semakin baik (Chairunnisa and Runadi, 2016).

Delapan senyawa monakolin memiliki konformasi yang lebih stabil serta nilai $\mathrm{Ki}$ yang lebih kecil dibandingkan simvastatin selaku ligan alami enzim HMG KoA reduktase sehingga diharapkan aktivitas senyawa monakolin tersebut mampu menghambat kerja enzim HMG KoA reduktase lebih baik dibandingkan simvastatin. Interaksi yang terjadi antara senyawa monakolin dengan enzim HMG KoA reduktase pada ligan alami yaitu melalui dua ikatan hidrogen pada Glu559 dan Asn 755. Asam monakolin L yang merupakan senyawa uji dengan hasil docking terbaik memiliki kedua interaksi serupa dengan ligan alami dan ditambah dengan dua ikatan hidrogen lainnya yaitu Ala751 dan Lys735 yang diduga menjadi penyebab konformasi kompleks protein dengan asam monakolin L lebih stabil dan memiliki nilai Ki terkecil.

\section{Penambatan Molekul Pigmen Monascus sp.}

Penambatan molekul pigmen Monascus sp. dilakukan untuk 33 senyawa pigmen yang terdiri dari 6 pigmen utama dan 27 derivat pigmen. Gambar struktur pigmen utama tersebut dapat dilihat pada Gambar 3.

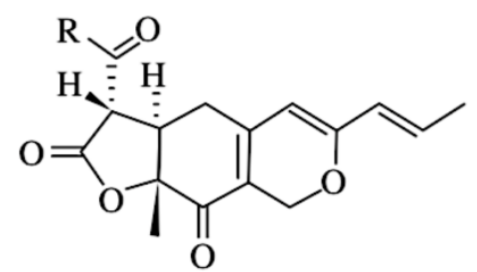

$$
\begin{gathered}
\text { Kuning } \\
\text { Monaskin n- } \mathrm{C}_{5} \mathrm{H}_{11}
\end{gathered}
$$

Ankaflavin $\mathrm{n}-\mathrm{C} 7 \mathrm{H} 15$

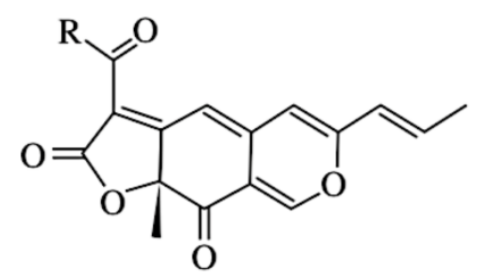

Orange Rubropunctatin $\mathrm{n}_{-} \mathrm{C}_{5} \mathrm{H}_{11}$ Monaskorubrin $\mathrm{n}-\mathrm{C}_{7} \mathrm{H}_{15}$<smiles>[R]C(=O)C1=C2C=C3C=C(C=CC)NC=C3C(=O)C2(C)OC1=O</smiles>

Merah

Rubropunctamine $\mathrm{n}-\mathrm{C}_{5} \mathrm{H}_{11}$ Monaskorubramin n-C $7 \mathrm{H}_{15}$

Gambar 3. Struktur Pigmen Utama Monascus sp. (Koli et al., 2017).

Kapang Monascus sp. selain menghasilkan 6 macam pigmen utama, juga memproduksi beberapa derivat pigmen yang secara alami terdapat pada beras angkak 
maupun yang merupakan hasil biosintesis. Beberapa di antaranya yang telah teridentifikasi sebagai derivat pigmen Monascus sp. ditunjukkan pada Gambar 4.<smiles>C/C=C/C1=CC2=CC(=O)C(C)(O)C(O)C2CO1</smiles>

FK17-P2B2

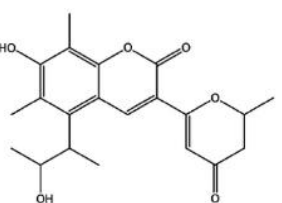

monankarin D

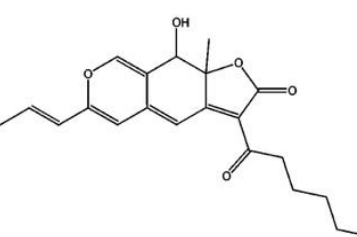

monaphilol $B$

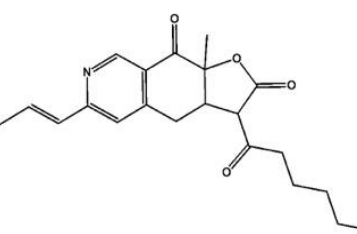

monaskopiridin A

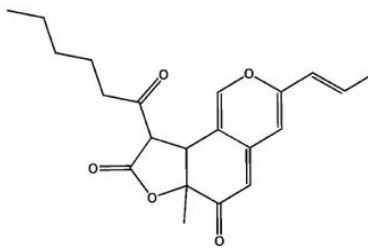

monasfluore A<smiles>CC(C)CC1=CC2=CC(=O)C(C)(C)C(O)C2CC1</smiles>

monascusone A

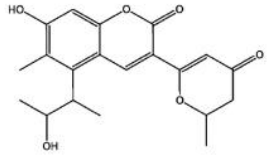

monankarin A

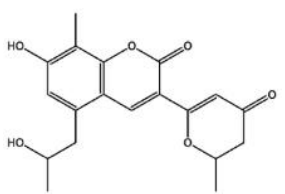

monankarin $\mathrm{E}$

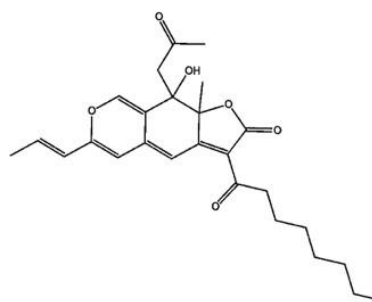

monaphilol C

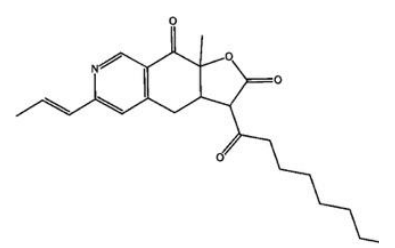

monaskopiridin

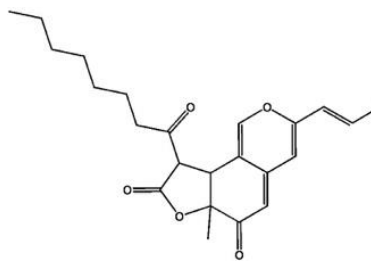

monasfluore B

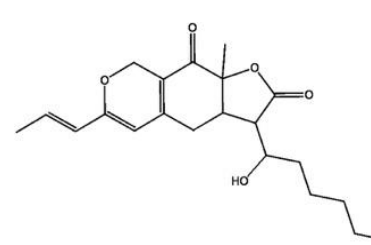

monascuspiloin

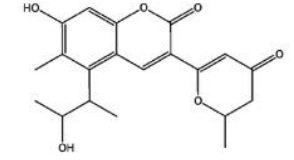

monankarin $\mathrm{B}$

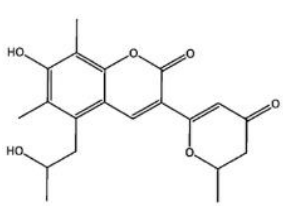

monankarin F

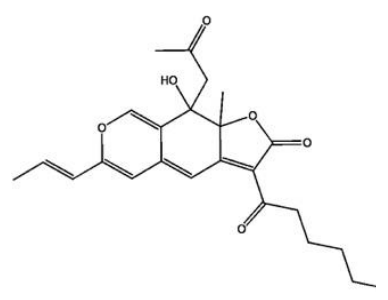

monaphilol D

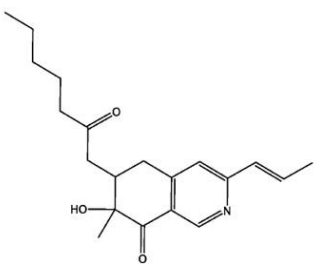

monaskopiridin $\mathrm{C}$

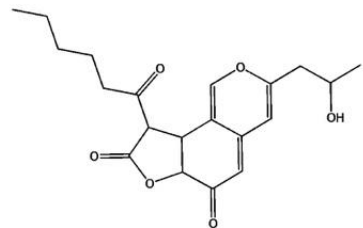

monasfluol A

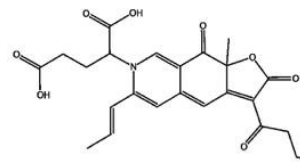

N-glutamil monaskorubramin

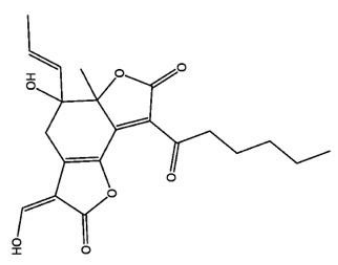

xanthomonasin A

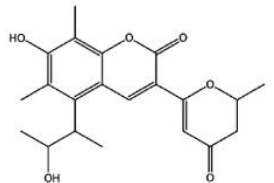

monankarin $\mathrm{C}$

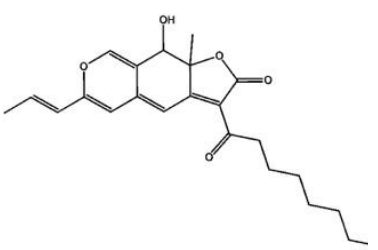

monaphilol A

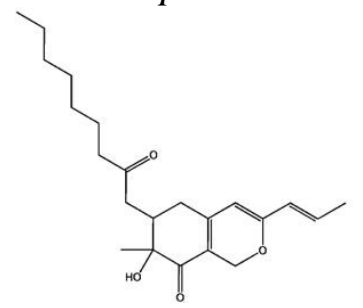

monaphilone A

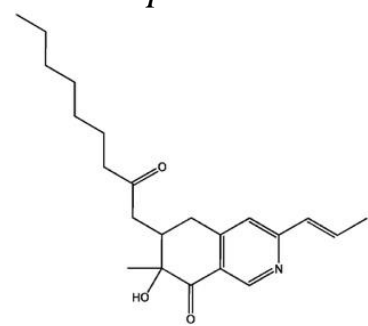

monaskopiridin D

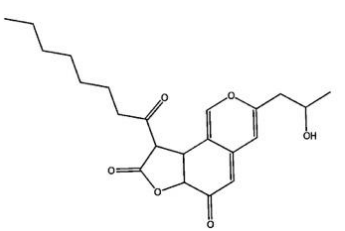

monasfluol B

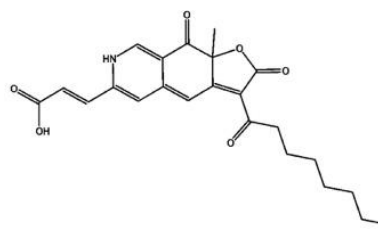

PP-V

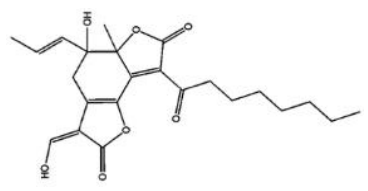

xanthomonasin $B$

$N$-glutamyl rubropuctamine

Gambar 4. Struktur senyawa derivat pigmen Monascus sp. 
Terdapat tiga reseptor hormon yang berkaitan dengan pertumbuhan kanker payudara yaitu resesptor estrogen alfa, estrogen beta dan aromatase. Hasil penambatan molekuler dan interaksi antara ligan dan reseptor dapat dilihat pada Tabel 3.

Tabel 3. Hasil docking pigmen Monascus sp. pada reseptor estrogen beta (1X7J)

\begin{tabular}{cllc}
\hline No & \multicolumn{1}{c}{ Nama Senyawa } & \multicolumn{1}{c}{ Ikatan Hidrogen } & $\begin{array}{c}\text { Energi Ikatan } \\
\text { (Kkal/mol) }\end{array}$ \\
\hline 1 & monankarin C & Arg346, Glu305, His475 & $-11,08$ \\
2 & PP-V & Arg346, Glu305, His475 & $-10,75$ \\
3 & monaskorubrin & His475 & $-10,41$ \\
4 & monaskin & His475 & $-10,32$ \\
5 & monankarin B & Arg346, Gly472 & $-10,19$ \\
6 & monascuspiloin & Gly472 & $-10,19$ \\
7 & ankaflavin & His475 & $-10,18$ \\
8 & monankarin D & Arg346, Gly472, Leu298 & $-10,13$ \\
9 & rubropunktatin & His475 & $-9,96$ \\
10 & rubropunktamin & His475 & $-9,89$ \\
11 & monasfluore A & His475 & $-9,89$ \\
12 & monasfluore B & & $-9,85$ \\
13 & monaskopiridin D & Gly472, His475 & $-9,16$ \\
14 & monankarin A & Leu298 & $-9,08$ \\
15 & monaskopiridin C & Gly472, His475 & $-8,96$ \\
16 & monaphilol D & His475 & $-8,69$ \\
17 & monaphilol C & His475 & $-8,67$ \\
18 & monaphilol B & Gly472, His475 & $-8,6$ \\
19 & monasfluol A & Arg346, Leu339 & $-8,49$ \\
20 & genistein (ligan alami) & Arg346, Glu305, His475 & $-8,39$ \\
21 & monaskorubramin & & $-8,03$ \\
22 & xanthomonasin B & & $-7,93$ \\
23 & FK17-P2B2 & & $-7,86$ \\
24 & monaphilone A & & $-7,68$ \\
25 & monasfluol B & & $-7,59$ \\
26 & xanthomonasin A & & $-7,25$ \\
27 & monascusone A & & $-7,23$ \\
28 & monaphilol A & & $-6,93$ \\
29 & monaskopiridin A & & $-6,3$ \\
30 & monaskopiridin B & $-5,35$ \\
31 & monankarin E & & $-4,73$ \\
32 & N-glutamyl rubropuctamine & $-4,15$ \\
33 & monankarin F & & $-3,43$ \\
34 & N-Glutamil & $-1,58$ \\
& monaskorubramin & & \\
\hline & Berdasarkan $~$ & & \\
\hline
\end{tabular}

Berdasarkan hasil pengujian pada Tabel 3, terlihat bahwa terdapat 19 pigmen dengan nilai energi ikatan lebih kecil dibandingkan ligan alaminya yaitu genistein. Genistein berpotensi kuat dalam pengobatan maupun pencegahan kanker payudara dikarenakan kemampuan antiproliferasinya. Genistein memiliki efek antiestrogenik melalui ikatan pada ER $\beta$ dengan menghambat aktivitas enzim yang terlibat dalam metabolisme estrogen (Bouker and Hilakivi-Clarke, 2000). Monankarin C memiliki nilai energi bebas ikatan terkecil yaitu $-11,08 \mathrm{Kkal} / \mathrm{mol}$ yang artinya memiliki konformasi 
kompleks paling stabil. Senyawa genistein membentuk ikatan hidrogen dengan Arg346, Glu305 dan His475. Interaksi yang sama juga dimiliki oleh monankarin $\mathrm{C}$ sehingga diharapkan afinitas senyawa monankarin $\mathrm{C}$ lebih baik dibandingkan ligan alami. Namun apabila dilihat hasil prediksi toksisitasnya, monankarin $\mathrm{C}$ positif bersifat mutagen, karsinogen dan toksik terhadap reproduksi.

Senyawa dengan nilai energi bebas ikatan terendah berikutnya adalah PP-V, monaskorubrin dan monaskin. Senyawa PP-V dan monaskorubrin bersifat toksik terhadap reproduksi maka senyawa terbaik yang berpotensi sebagai antikanker payudara yakni pigmen monaskin. Pigmen monaskin merupakan salah satu dari 6 pigmen utama dan berdasarkan hasil prediksi toksisitas dinyatakan tidak toksik. Monaskin juga memiliki nilai energi ikatan lebih kecil dibandingkan ligan alami sehingga memiliki konformasi yang stabil. Terdapat satu ikatan hidrogen pada monaskin yaitu His475 yang juga terdapat pada ikatan hidrogen ligan alami. Oleh karena itu, monaskin diperkirakan berpotensi untuk dikembangkan menjadi antikanker payudara yang bekerja pada reseptor ER $\beta$.

Tabel 4. Hasil docking pigmen Monascus sp. pada reseptor estrogen alfa (3ERT)

\begin{tabular}{|c|c|c|c|c|c|}
\hline No & Nama Senyawa & $\begin{array}{c}\text { Energi } \\
\text { Ikatan } \\
\text { (Kkal/mol) } \\
\end{array}$ & No & Nama Senyawa & $\begin{array}{c}\text { Energi } \\
\text { Ikatan } \\
\text { (Kkal/mol) }\end{array}$ \\
\hline 1 & $\begin{array}{l}\text { 4-hidroksitamoxifen } \\
\text { (ligan alami) }\end{array}$ & $-11,64$ & 18 & rubropunktatin & $-8,64$ \\
\hline 2 & monaskopiridin D & $-11,19$ & 19 & rubropunktamin & $-8,52$ \\
\hline 3 & monankarin $\mathrm{C}$ & $-11,07$ & 20 & monasfluol A & $-8,28$ \\
\hline 4 & monankarin B & $-10,83$ & 21 & monascusone A & -8 \\
\hline 5 & monaskopiridin $\mathrm{C}$ & $-10,82$ & 22 & monaskin & $-7,79$ \\
\hline 6 & monankarin $D$ & $-10,65$ & 23 & monankarin $\mathrm{E}$ & $-7,27$ \\
\hline 7 & monasfluore B & $-10,48$ & 24 & $N$-glutamyl rubropuctamine & $-6,7$ \\
\hline 8 & monaskorubrin & $-9,91$ & 25 & $F K 17-P 2 B 2$ & $-6,46$ \\
\hline 9 & monasfluore A & $-9,81$ & 26 & monankarin $\mathrm{A}$ & $-5,63$ \\
\hline 10 & ankaflavin & $-9,79$ & 27 & monaphilol A & $-5,35$ \\
\hline 11 & monasfluol B & $-9,64$ & 28 & monaphilol D & $-4,75$ \\
\hline 12 & monascuspiloin & $-9,62$ & 29 & monaphilol C & $-4,69$ \\
\hline 13 & monaskorubramin & $-9,58$ & 30 & monaskopiridin A & $-3,77$ \\
\hline 14 & PP-V & $-9,32$ & 31 & monaphilol B & $-2,77$ \\
\hline 15 & xanthomonasin B & $-9,01$ & 32 & N-glutamil monaskorubramin & $-2,62$ \\
\hline 16 & xanthomonasin $A$ & $-8,9$ & 33 & monankarin $\mathrm{F}$ & $-2,27$ \\
\hline 17 & monaphilone A & $-8,85$ & 34 & monaskopiridin B & $-0,11$ \\
\hline
\end{tabular}

Tabel 4 merupakan hasil docking antara pigmen Monascus sp. dengan reseptor estrogen alfa. Berdasarkan hasil tersebut, terlihat bahwa ligan alami yaitu 4hidroksitamoksifen yang juga merupakan obat antikanker payudara yang banyak 
digunakan memiliki nilai energi bebas ikatan paling kecil dibandingkan dengan semua pigmen Monascus sp.

Tabel 5 merupakan hasil docking antara pigmen Monascus sp. dengan reseptor aromatase. Berdasarkan tabel tersebut, dapat dilihat bahwa pigmen Monascus sp. tidak memiliki energi bebas ikatan yang lebih kecil dibandingkan dengan ligan alami exemestane.

Tabel 5. Hasil docking pigmen Monascus sp. pada reseptor aromatase (3S7S)

\begin{tabular}{llcclc}
\hline No & Nama Senyawa & $\begin{array}{c}\text { Energi } \\
\text { Ikatan } \\
\text { (Kkal/mol) }\end{array}$ & No & \multicolumn{1}{c}{ Nama Senyawa } & $\begin{array}{c}\text { Energi } \\
\text { Ikatan } \\
\text { (Kkal/mol) }\end{array}$ \\
\hline 1 & Exemestan (ligan alami) & $-12,56$ & 18 & monaphilone A & $-6,28$ \\
2 & ankaflavin & $-9,81$ & 19 & monankarin A & $-6,15$ \\
3 & monaskorubrin & $-9,39$ & 20 & monaphilol C & $-6,15$ \\
4 & monasfluore A & $-8,79$ & 21 & PP-V & $-5,95$ \\
5 & monaskin & $-8,67$ & 22 & monaphilol D & $-5,45$ \\
6 & rubropunktamin & $-8,59$ & 23 & monasfluol A & $-5,34$ \\
7 & monascuspiloin & $-8,32$ & 24 & monankarin E & $-4,63$ \\
8 & monankarin B & $-8,28$ & 25 & monaphilol B & $-4,5$ \\
9 & monaskopiridin C & $-8,21$ & 26 & xanthomonasin A & $-4,14$ \\
10 & rubropunktatin & $-8,1$ & 27 & N-glutamyl rubropuctamine & -4 \\
11 & monaskopiridin D & $-8,09$ & 28 & xanthomonasin B & $-3,93$ \\
12 & monankarin D & $-8,06$ & 29 & N-glutamil monaskorubramin & $-2,82$ \\
13 & FK17-P2B2 & $-7,86$ & 30 & monaphilol A & 1,95 \\
14 & monankarin C & $-7,59$ & 31 & monaskopiridin B & 2,38 \\
15 & monasfluore B & $-7,33$ & 32 & monasfluol B & 2,74 \\
16 & monaskorubramin & $-7,16$ & 33 & monankarin F & 4,53 \\
17 & monascusone A & $-6,34$ & 34 & monaskopiridin A & 9,52 \\
\hline
\end{tabular}

\section{Verifikasi Metode Prediksi Toksisitas}

Verifikasi metode dilakukan untuk membuktikan bahwa metode prediksi yang digunakan dapat memberikan hasil yang sesuai dengan spesifikasi metode tersebut. Pada Tabel 6 dapat dilihat parameter statistik Cooper yang digunakan meliputi sensitivitas, spesifisitas, akurasi, prediktivitas positif, prediktivitas negatif, rasio positif palsu, rasio negatif palsu dan receiver operating characteristic (ROC) (Valerio and Cross, 2012).

Model klasifikasi nilai keberterimaan dari Cooper adalah lebih besar dari 0.5 kecuali untuk rasio positif palsu dan rasio negatif palsu adalah lebih kecil dari 0,5 (OECD, 2007). Hasil verifikasi seluruh metode prediksi mutagenitas, karsinogenitas dan toksisitas reproduksi memberikan nilai sensitivitas, spesifisitas, akurasi, prediktivitas positif, dan prediktivitas negatif yaitu $\geq 0,8$ seperti yang terlihat pada Tabel 6 . Hal ini menunjukkan bahwa semua metode prediksi tersebut dapat memprediksi dengan benar baik senyawa 
toksik dan tidak toksik sehingga dapat digunakan untuk memprediksi toksisitas senyawa uji.

Tabel 6. Hasil verifikasi metode prediksi toksisitas

\begin{tabular}{|c|c|c|c|c|c|c|c|c|c|}
\hline Metode Prediksi & Se & Sp & $\mathbf{Q}$ & $\mathbf{P P}$ & $\mathbf{N P}$ & FPR & FNR & ROC + & ROC - \\
\hline \multicolumn{10}{|l|}{ Mutagenitas } \\
\hline ADMET predictor & 0,92 & 0,84 & 0,88 & 0,85 & 0,91 & 0,16 & 0,08 & 5,75 & 10,5 \\
\hline QSAR Toolbox & 0,8 & 0,88 & 0,84 & 0,87 & 0,81 & 0,12 & 0,2 & 6,67 & 4,4 \\
\hline Karsinogenitas & & & & & & & & & \\
\hline QSAR Toolbox & 0,88 & 0,8 & 0,84 & 0,81 & 0,87 & 0,2 & 0,12 & 4,4 & 6,67 \\
\hline Toksisitas reproduksi & & & & & & & & & \\
\hline ADMET predictor & 0,8 & 0,84 & 0,82 & 0,83 & 0,81 & 0,16 & 0,2 & 5 & 4,2 \\
\hline
\end{tabular}

Semua metode prediksi memiliki nilai rasio positif palsu dan rasio negatif palsu di antara 0,1-0,2 atau lebih kecil dari 0,5 seperti yang disyaratkan OECD. Semakin kecil nilai rasio positif palsu dan rasio negatif palsu maka kesalahan prediksi akan semakin kecil sehingga hasil prediksi semakin baik. Nilai Receiver Operating Characteristic merupakan perbandingan antara nilai yang diprediksi benar dengan nilai yang diprediksi salah. Nilai ROC memberikan hasil yang berbeda signifikan jika nilainya lebih besar dari 2 (Valerio and Cross, 2012). Hasil verifikasi semua metode prediksi memberikan nilai ROC > 2 untuk prediksi mutagenitas, karsinogenitas dan toksisitas reproduksi. Berdasarkan verifikasi metode prediksi toksisitas yang telah dilakukan, seluruh hasil memenuhi persyaratan parameter statistik Cooper sehingga metode prediksi tersebut dapat digunakan sesuai tujuan penggunaannya.

\section{Prediksi Toksisitas Akut}

Toksisitas akut oral merupakan efek toksik suatu senyawa yang terjadi setelah diberikan melalui administrasi oral dengan dosis tunggal maupun berulang dalam jangka waktu 24 jam. Uji toksisitas akut umumnya dilakukan untuk menentukan nilai Lethal Dose $50\left(\mathrm{LD}_{50}\right)$ yaitu dosis yang dapat menyebabkan kematian sebanyak $50 \%$ dari jumlah hewan uji (OECD, 2007). Prediksi toksisitas akut dilakukan dengan menggunakan perangkat lunak ADMET predictor. Perangkat lunak ini menggunakan 7.150 senyawa khas dari dua database yaitu Registry of Toxic Effects of Chemical Substances (RTECS) dan ChemIDplus. Nilai LD $_{50}$ yang diperoleh kemudian dibagi menjadi beberapa kategori. Kategori nilai $\mathrm{LD}_{50}$ berdasarkan Lu's Handbook of Toxicology diklasifikasikan sebagai praktis tidak toksik (>15 g/kg), toksisitas ringan (5-15 g/kg), toksisitas sedang $(0,5-5 \mathrm{~g} / \mathrm{kg})$, sangat toksik $(50-500 \mathrm{mg} / \mathrm{kg})$, amat sangat toksik $(5-50 \mathrm{mg} / \mathrm{kg})$, dan supertoksik $(<5$ 
$\mathrm{mg} / \mathrm{kg}$ ). Berdasarkan pengujian prediksi toksisitas akut oral pada tikus, maka diketahui bahwa terdapat 6 senyawa dengan kategori sangat toksik dan 41 senyawa dengan kategori toksisitas sedang. Semakin kecil nilai $\mathrm{LD}_{50}$ maka senyawa tersebut semakin toksik. Setelah nilai $\mathrm{LD}_{50}$ dikategorikan, maka hasilnya dapat dilihat pada Tabel 7 berikut.

Tabel 7. Hasil prediksi toksisitas akut

\begin{tabular}{|c|c|c|}
\hline \multicolumn{2}{|c|}{ Toksisitas Sedang } & \multirow{2}{*}{$\begin{array}{c}\text { Sangat Toksik } \\
\text { Pigmen } \\
\end{array}$} \\
\hline Monakolin & Pigmen & \\
\hline $\begin{array}{l}\text { 1. 3-hidroksi-3,5- } \\
\text { dihidromonakolin L }\end{array}$ & 1. Ankaflavin & 1. monaphilol $\mathrm{C}$ \\
\hline 2. kompaktin & 2. monaskorubramin & 2. monaphilol D \\
\hline 3. dehidromonakolin $\mathrm{K}$ & 3. monaskin & 3. monasfluol A \\
\hline 4. asam dihidromonakolin $\mathrm{L}$ & 4. monaskorubrin & 4. monasfluol B \\
\hline 5. monakolin $\mathrm{L}$ & 5. rubropunktamin & 5. monasfluore A \\
\hline 6. asam monakolin $\mathrm{J}$ & 6. rubropunktatin & 6. monasfluore $B$ \\
\hline 7. monakolin $\mathrm{J}$ & 7. $F K 17-P 2 B 2$ & \\
\hline 8. asam monakolin $\mathrm{K}$ & 8. monankarin A & \\
\hline 9. monakolin $\mathrm{K}$ & 9. monankarin $\mathrm{B}$ & \\
\hline 10. asam monakolin $\mathrm{L}$ & 10. monankarin $\mathrm{C}$ & \\
\hline 11. monakolin $\mathrm{M}$ & 11. monankarin D & \\
\hline 12. asam monakolin $\mathrm{M}$ & 12. monankarin $\mathrm{E}$ & \\
\hline 13. monakolin $\mathrm{X}$ & 13. monankarin $\mathrm{F}$ & \\
\hline 14. asam monakolin $X$ & 14. monaphilol A & \\
\hline & 15. monaphilol B & \\
\hline & 16. monaphilone A & \\
\hline & 17. monaskopiridin A & \\
\hline & 18. monaskopiridin B & \\
\hline & 19. monaskopiridin $\mathrm{C}$ & \\
\hline & 20. monaskopiridin D & \\
\hline & 21. monascusone A & \\
\hline & 22. monascuspiloin & \\
\hline & 23. N-Glutamil & \\
\hline & monaskorubramin & \\
\hline & 24. $N$-glutamyl rubropuctamine & \\
\hline & 25. PP-V & \\
\hline & 26. xanthomonasin $A$ & \\
\hline & 27. xanthomonasin $B$ & \\
\hline
\end{tabular}

\section{Prediksi Mutagenitas}

Mutasi adalah perubahan permanen struktur materi genetik dalam sel. Sedangkan mutagen merupakan agen yang meningkatkan terjadinya mutasi pada populasi sel dan atau organisme. Istilah mutasi berlaku untuk perubahan genetik yang dapat termanifestasi pada tingkat fenotip dan modifikasi DNA yang diketahui secara jelas termasuk perubahan pasangan basa yang spesifik dan translokasi kromosom (European Chemicals Agency, 2016). Hasil prediksi senyawa uji terhadap 47 senyawa menggunakan perangkat lunak ADMET predictor dan QSAR Toolbox dapat dilihat pada Tabel 8.

Tabel 8. Hasil prediksi mutagenitas 


\begin{tabular}{|c|c|c|c|}
\hline \multicolumn{2}{|r|}{ ADMET } & \multirow{2}{*}{$\begin{array}{l}\text { QSAR } \\
\text { Pigmen }\end{array}$} & \multirow{2}{*}{$\begin{array}{c}\text { Kesimpulan } \\
\text { Pigmen } \\
\end{array}$} \\
\hline Monakolin & Pigmen & & \\
\hline 1. asam & Monaskin & Monaskorubramin & 1. FK17-P2B2 \\
\hline \multirow{14}{*}{ Monakolin X } & Monaskorubrin & $F K 17-P 2 B 2$ & 2. monankarin $\mathrm{A}$ \\
\hline & 3. Rubropunktamin & monankarin A & 3. monankarin $\mathrm{B}$ \\
\hline & 4. Rubropunktatin & monankarin B & 4. monankarin $\mathrm{C}$ \\
\hline & 5. $F K 17-P 2 B 2$ & monankarin $\mathrm{C}$ & 5. monankarin $\mathrm{D}$ \\
\hline & 6. Monaphilol A & monankarin D & 6. monankarin $\mathrm{E}$ \\
\hline & 7. Monaphilol B & monankarin $\mathrm{E}$ & 7. monankarin $\mathrm{F}$ \\
\hline & 8. Monaphilol C & monankarin $\mathrm{F}$ & 8. monasfluol A \\
\hline & 9. Monaphilol D & monascusone A & 9. $\mathrm{N}$-glutamil \\
\hline & 10. Monasfluol A & 10. monasfluol A & monaskorubramin \\
\hline & 11. N-glutamil & 11. monasfluol B & 10. $N$-glutamyl \\
\hline & monaskorubramin & 12. monasfluore A & rubropuctamine \\
\hline & 12. N-glutamyl & 13. monasfluore B & \\
\hline & rubropuctamine & 14. xanthomonasin $A$ & \\
\hline & 13. PP-V & 15. xanthomonasin B & \\
\hline
\end{tabular}

Senyawa dengan hasil mutagenitas yang berbeda antara dua perangkat lunak maka diprediksi lebih lanjut karakteristik mekanisme mutagennya melalui kemampuan untuk berikatan dengan DNA (DNA binding). Prediksi DNA binding menjelaskan pengembangan profiler baru yang menyusun fragmen kimia organik mekanistik (dalam bentuk structural alerts) untuk pengikatan senyawa organik ke DNA. Profiler dibuat setelah pemetaan structural alerts (SA) yang ada untuk mutagenitas dan karsinogenitas. Secara keseluruhan terdapat 60 SA baru yang telah dibuat (Benigni and Bossa, 2011). Berdasarkan hasil prediksi mutagenitas dengan dua perangkat lunak yakni ADMET predictor dan QSAR Toolbox lalu dilanjutkan dengan prediksi DNA binding maka disimpulkan total senyawa uji positif mutagen yaitu 10 senyawa. Senyawa monasfluol A dan $F K 17-P 2 B 2$ diprediksi positif mutagen karena memiliki SA berupa karbonil $\alpha, \beta$ tidak jenuh. Senyawa dengan karbonil alfa beta tidak jenuh merupakan molekul reaktif biselektrofil yang dapat berinteraksi dengan makromolekul biologis yang kaya elektron. Karena adanya konjugasi dengan gugus karbonil, karbon beta terpolarisasi positif dan menjadi target nukleofilik, termasuk dalam kategori classic Michael type addition (Koleva et al., 2008). Struktur alert lainnya yaitu kumarin yang terdapat pada pigmen monankarin $\mathrm{A}$, monankarin $\mathrm{B}$, monankarin $\mathrm{C}$, monankarin $\mathrm{D}$, monankarin $\mathrm{E}$ dan monankarin $\mathrm{F}$. Senyawa kumarin yang terepoksidasi melalui mekanisme SN2 (Substitusi Nukleofilik 2) dapat membentuk ikatan kovalen dengan nukelofil biologis seperti DNA (Lake, 1999); (Woo and Lai, 2005). Senyawa N-glutamil monaskorubramin dan N-glutamyl rubropuctamine berpotensi terjadi pengikatan DNA melalui mekanisme SN1 yang ditandai dengan structure alert berupa amina alifatik tersier. Mekanisme DNA binding terjadi 
dengan pembentukan ion iminium. Ion iminium reaktif terbentuk dari metabolisme P450 (Benigni and Bossa, 2011). Oleh karena itu, senyawa N-glutamil monaskorubramin dan $N$ glutamyl rubropuctamine diprediksi positif mutagen.

\section{Prediksi Karsinogenitas}

Karsinogen adalah zat atau campuran zat yang dapat menginduksi kanker atau meningkatkan insidensinya. Zat yang telah menginduksi tumor jinak dan ganas pada hewan dalam studi eksperimental juga dianggap atau diduga karsinogen bagi manusia kecuali ada bukti kuat bahwa mekanisme pembentukan tumor tidak relevan untuk manusia (European Chemicals Agency, 2016). Prediksi karsinogenitas dilakukan menggunakan perangkat lunak QSAR Toolbox dan hasilnya dapat dilihat pada Tabel 9.

Tabel 9. Hasil Prediksi Karsinogenitas

\begin{tabular}{lll}
\hline \multicolumn{1}{c}{ Monakolin } & & \multicolumn{1}{c}{ Pigmen } \\
\hline 1. kompaktin & 1. & monaskorubramin \\
2. dehidromonakolin K & 2. & FK17-P2B2 \\
3. asam monakolin K & 3. & monankarin A \\
4. monakolin K & 4. & monankarin B \\
5. monakolin X & 5. & monankarin C \\
6. asam monakolin X & 6. monankarin D \\
& 7. monankarin E \\
& 8. monankarin F \\
& 9. monascusone A \\
& 10. monasfluol A \\
& 11. monasfluol B \\
& 12. monasfluore A \\
& 13. monasfluore B \\
& 14. xanthomonasin A \\
& 15. xanthomonasin B \\
\hline
\end{tabular}

Berdasarkan data pada Tabel 9, diketahui bahwa sebanyak 6 senyawa monakolin dan 15 pigmen Monascus sp. positif karsinogen sedangkan 8 senyawa monakolin dan 18 pigmen Monascus sp. negatif karsinogen. Dari total 21 senyawa yang diprediksi karsinogen, 6 di antaranya merupakan karsinogen nongenotoksik dan 15 lainnya merupakan karsinogen genotoksik kemudian dilihat struktur alerts yang menyebabkan sifat karsinogenitas pada senyawa uji. Senyawa kompaktin, dehidromonakolin K, monakolin K, asam monakolin $\mathrm{K}$, monakolin $\mathrm{X}$ dan asam monakolin $\mathrm{X}$ memiliki SA berupa asam $\mathrm{n}$ alkilkarboksilat tersubstitusi. Senyawa dengan SA tersebut berpotensi bersifat reaktif sebagai proliferator peroksisom (PP). Terdapat dua hipotesis yang memprediksi induksi hepatokarsinogenesis oleh PP pada hewan pengerat yaitu melalui peningkatan kerusakan DNA melalui induksi stress oksidatif (Reddy and Rao, 1989) dan perubahan kontrol 
pertumbuhan hepatosit dengan peningkatan proliferasi sel atau penurunan apoptosis (Corton et al., 2000).

Senyawa monaskorubramin diprediksi sebagai karsinogen genotoksik karena memiliki SA Polycylic Aromatic Hydrocarbon (PAH). PAH dengan struktur aromatik terkonjugasi yang relatif planar membutuhkan aktivasi metabolik berupa pembentukan diol-epoksida. Proses ini menghasilkan senyawa diol epoksida yang dapat berinteraksi dengan DNA dan menyebabkan alkilasi DNA (Benigni and Bossa, 2011).

Struktur alerts berikutnya adalah karbonil $\alpha, \beta$ tidak jenuh yang terdapat pada senyawa FK17-P2B2, monascusone A, monasfluol A, monasfluol B, monasfluore A, monasfluore B, xanthomonasin A dan xanthomonasin B. Selain itu, terdapat enam senyawa yang memiliki struktur alert berupa kumarin dan furokumarin yaitu senyawa monankarin A, monankarin B, monankarin $\mathrm{C}$, monankarin D, monankarin $\mathrm{E}$ dan monankarin $\mathrm{F}$. Kedua SA ini bersifat karsinogen selain juga bersifat mutagen seperti yang telah dijelaskan sebelumnya.

\section{Prediksi Toksisitas Reproduksi}

Toksisitas reproduksi adalah efek merugikan pada fungsi seksual dan kesuburan pada pria dan wanita dewasa, serta toksisitas perkembangan pada keturunannya (European Chemicals Agency, 2016). Hasil prediksi toksisitas reproduksi secara lengkap dapat dilihat pada Tabel 10 .

Prediksi toksisitas reproduksi dilakukan menggunakan perangkat lunak ADMET predictor. Hasil prediksi pada Tabel 10 menunjukkan 3 senyawa monakolin dan 23 pigmen monascus positif toksik. Selain itu, 11 senyawa monakolin dan 10 pigmen Monascus sp. negatif toksik. Pada perangkat lunak ADMET predictor tidak dapat diketahui struktur atau gugus fungsi tertentu yang menjadi faktor penentu toksisitas reproduksi suatu senyawa. Sehingga tidak diketahui mekanisme toksisitas dari senyawa yang diprediksi toksik terhadap reproduksi.

Tabel 10. Hasil Prediksi Toksisitas Reproduksi

\begin{tabular}{lll}
\hline \multicolumn{1}{c}{ Monakolin } & \multicolumn{2}{c}{ ADMET } \\
\hline 1. dehidromonakolin $\mathrm{K}$ & 1. & monaskorubramin \\
2. asam monakolin X & 2. & monaskorubrin \\
3. asam monakolin M & 3. & rubropunktamin \\
& 4. & rubropunktatin \\
& 5. & monankarin A \\
& 6. & monankarin B \\
& 7. & monankarin C \\
& 8. & monankarin D
\end{tabular}




\begin{tabular}{ll}
\hline 9. & monankarin E \\
10. monankarin F \\
11. monaphilol A \\
12. monaphilol B \\
13. PP-V \\
14. monaphilol C \\
15. monaphilol D \\
16. monaphilone A \\
17. monaskopiridin C \\
18. monaskopiridin D \\
19. monasfluol A \\
20. monasfluol B \\
21. monasfluore B \\
22. N-glutamil monaskorubramin \\
23. N-glutamyl rubropuctamine \\
\hline
\end{tabular}

\section{KESIMPULAN}

Aktivitas antikolesterol senyawa monakolin ditunjukkan oleh asam monakolin L dengan afinitas terhadap enzim HMG KoA reduktase. Sedangkan aktivitas antikanker pigmen Monascus sp. ditunjukkan oleh pigmen monaskin dengan afinitas terhadap reseptor estrogen beta. Kedua senyawa ini juga diprediksi aman berdasarkan hasil prediksi toksisitas. Terdapat 7 senyawa monakolin yaitu 3-hidroksi-3,5-dihidromonakolin L, asam dihidromonakolin $\mathrm{L}$, monakolin $\mathrm{L}$, asam monakolin $\mathrm{J}$, monakolin $\mathrm{J}$, asam monakolin $\mathrm{L}$, monakolin M dan 5 pigmen Monascus sp. yaitu ankaflavin, monaskin, monaskopiridin A, monaskopiridin B dan monascuspiloin yang dinyatakan tidak toksik. Tujuh pigmen Monascus sp. yang terdiri dari monankarin A, monankarin B, monankarin $\mathrm{C}$, monankarin $\mathrm{D}$, monankarin $\mathrm{E}$, monankarin $\mathrm{F}$, dan monasfluol A bersifat positif mutagen, karsinogen dan toksik terhadap reproduksi Penelitian ini masih berupa prediksi secara in silico sehingga masih perlu dibuktikan dan dilanjutkan secara eksperimental. Selanjutnya dapat dilakukan optimasi struktur senyawa asam monakolin L dan pigmen monaskin sehingga bisa dikembangkan menjadi kandidat obat baru.

\section{DAFTAR PUSTAKA}

Benigni, R., and Bossa, C. 2011. Mechanisms of Chemical Carcinogenicity and Mutagenicity: A Review with Implications for Predictive Toxicology. Chemical Reviews 111, 2507-2536.

Bouker, K. B., and Hilakivi-Clarke, L. 2000. Genistein: Does It Prevent or Promote Breast Cancer?. Environmental Health Perspectives 108, 701-708.

Chairunnisa, A., and Runadi, D. 2016. Aktivitas Kalkon Terhadap Reseptor Estrogen $\beta$ (ER- $\beta$ ) Sebagai Antikanker Payudara Secara In Vitro dan In Silico: Review. Farmaka 14, 1-8. 
Corton, J. C., Lapinskas, P., and Gonzalez, F. J. 2000. Central Role of PPARa in The Mechanism of Action of Hepatocarcinogenic Peroxisome Proliferators. Mutation Research 448, 139-151.

Dassault Systèmes BIOVIA. Discovery Studio. 2017. Dassault Systèmes, San Diego.

Fatima, N., Kalsoom, A., Mumtaz, A., and Muhammad, S. A. 2014. Computational drug designing of fungal pigments as potential aromatase inhibitors. Bangladesh Journal Pharmacological 9, 575-579.

Frisch, M. J., Trucks, G. W., Schlegel, H. B., Scuseria, G. E., Robb, M. A., Cheeseman, J. R., Scalmani, G., Barone, V., Petersson, G. A., Nakatsuji, H., Li, X., and Caricato, M., 2016. Gaussian, Inc., Wallingford CT.

Guidance Document on the Validation of (Quantitative) Structure-Activity Relationship Models ENV/JM/MONO 2, 2007. OECD.

Guidance on Labelling and Packaging in Accordance with Regulation (EC) No 1272/2008, 2016. European Chemicals Agency, Finlandia.

Heinz, T., Schuchardt, J. P., Moller, K., Hadji, P., and Hahn, A. 2016. Low Daily Dose of $3 \mathrm{mg}$ Moheinznacolin K from RYR Reduces The Concentration of LDL-C in A Randomized, Placebo-Controlled Intervention. Nutrition Research 36, 1162-1170.

Ho, B. Y., and Pan, T. M. 2009. The Monascus Metabolite Monakolin K Reduces Tumor Progression and Metastasis of Lewis Lung Carcinoma Cells. Journal of Agricultural and Food Chemistry 57, 8258-8265.

Koleva, Y. K., Madden, J. C., and Cronin, M. T. D. 2008. Formation of Categories from Structure-Activity Relationships to Allow Read-Across for Risk Assessment: Toxicity of $\alpha, \beta$-Unsaturated Carbonyl Compounds. Chemical Research in Toxicology 21, 2000-2012.

Koli, S. H., Suryawanshi, R. K., Patil, C. D., and Patil, S. V. 2017. Bio-pigmentation and Biotechnological Implementatios. John Wiley \& Sons Inc, USA.

Lake, B. G. 1999. Coumarin Metabolism, Toxicity and Carcinogenicity: Relevance for Human Risk Assessment. Food and Chemical Toxicology 37, 423-453.

Morris, G. M., Huey, R., Lindstrom, W., Sanner, M. F., Belew, R. K., Goodsell, D. S., and Olson, A. J. 2009. Autodock4 and AutoDockTools4: Automated Docking with Selective Receptor Flexiblity. Journal of Computational Chemistry 16, 2785-91.

Nguyen, T., Karl, M., and Santini, A. 2017. Red Yeast Rice. Foods Multidisciplinary Digital Publishing Institute 6, 19.

O’Boyle, N. M., Banck, M., James, C. A., Morley, C., Vandermeersch, T., and Hutchison, G. R. 2011. Open Babel: An Open Chemical Toolbox. Journal of Cheminformatics 3, 33.

Raies, A. B., and Bajic, V. B. 2016. In Silico Toxicology: Computational Methods for The Prediction of Chemical Toxicity. Wiley Interdisciplinary Reviews: Computational Molecular Science 6, 147-172.

Reddy, J. K., dan Rao, M.S. 1989. Oxidative DNA Damage Caused by Persistent Peroxisome Proliferation: Its Role in Hepatocarcinogenesis. Mutation Research 214, 63-68.

Sabry, O. M. M. 2016. A New HPLC Method for Analysis of Natural Monakolin K in Red Yeast Rice Pharmaceutical Preparations. Journal of Pharmacognosy and Natural 


\section{Products 1, 1-4.}

Seyedin, A., Yazdian, F., Hatamian-Zarmi, A., Rasekh, B., and Mir-derikvand, M. 2015. Natural Pigment Production by Monascus Purpureus: Bioreactor Yield Improvement through Statistical Analysis. Applied Food Biotechnology 2, 23-30.

Sherman, W., Beard, H. S., and Farid, R. 2006. Use of An Induced Fit Receptor Structure in Virtual Screening. Chemical Biology \& Drug Design 67, 83-84.

Valerio, L. G., and Cross K. P. 2012. Characterization and Validation of An In Silico Toxicology Model to Predict The Mutagenic Potential of Drug Impurities. Toxicology and Applied Pharmacology 260, 209-221.

Watkins, P. B., pisetsky, D. S., Park, K., Kaplowitz, N., Roth, R. A., and Uetrecht, J. 2018. Simulations Plus Company.

Wongjewboot, I., and Kongruang, S. 2011. pH stability of ultrasonic thai isolated monascus purpureus pigments. International Journal of Bioscience. Biochemistry and Bioinformatics 1, 79-83.

Woo, Y. T., and Lai, D. Y. 2005. Predictive toxicology. Taylor and Francis, UK.

Yuliana, A., Singgih, M., Julianti, E., and Blanc, P. J. 2017. Derivates of Azaphilone Monascus Pigments. Biocatalysis and Agricultural Biotechnology 9, 183-194. 